\title{
Rewards System and Employee Retention during COVID 19 Pandemic in Nigeria
}

\author{
Zoakah, Dogonyaro Joy *, Bulus Pikitda ${ }^{* *}$, Comfort Iliya ${ }^{* * *}$ \\ * Department Of Business Administration, Faculty Of Management Sciences, University Of Jos \\ ${ }^{* *}$ Texila American University, Guyana \\ ** Ph.D Student, Department Of Business Administration, Faculty Of Management Sciences, University Of Jos \\ DOI: 10.29322/IJSRP.11.07.2021.p11547 \\ http://dx.doi.org/10.29322/IJSRP.11.07.2021.p11547
}

\begin{abstract}
This study targeted on rewards system and employees' retention throughout COVID-19 pandemic in Nigeria. The study used Jos University Teaching Hospital (JUTH) as the study area. Descriptive survey study was used and target population of four hundred employees' cutting across nine units were considered. A sample of one hundred participants was drawn using both purposive and simple random techniques. The questionnaire used was adapted from the study of Oyoo, Mwandihi and Musiega (2016). A total of eighty questionnaires were completed and returned. Simple percentages, mean, standard deviation and spearman rank correlation coefficient were used for data analysis. The study showed that most of the extrinsic rewards of the organization were not provided during the pandemic. It was revealed that intrinsic and extrinsic rewards had significant positive effect on employees' retention during COVID19 pandemic in JUTH. The study concluded that rewards system affected employees' retention during COVID-19 in JUTH. The study recommended that management of JUTH should redesign their intrinsic reward system policy in a manner that superior performance by employees will attract special rewards. Management of JUTH ought to make sure that employee edges, allowances and promotions deserved should be given to them at the proper time and government ought to make sure that reward system for JUTH workers takes cognizance of novel diseases like pandemics so as to minimize their consequences on employees' retention.
\end{abstract}

Index Terms- Rewards System, Employees' Retention, COVID19 Pandemic, JUTH

\section{INTRODUCTION}

$\mathrm{T}$ The emergence of the novel COVID-19 virus seems to have aggravated the hitherto economic hardship individuals, especially employees are exposed to in their work places. The impact of the pandemic in workplaces across Nigeria has been devastating considering its perceived consequences on employees' reward and retention. The novel COVID-19 Pandemic has revolutionized the way employers think about working; consequently, our approach to rewards needs to be redefined in line with the emerging new normal. Productive employee retention is a careful effort made by employers to generate and strengthen an environment that motivates contemporary employees to remain employed by having policies and practices in place that address their diverse needs. Under such conditions, retention has become a great challenge for the business and organizations (Sharma, et al, 2010). A strong retention strategy becomes an important factor in analyzing the effects on a pandemic on employees' productivity. Retention of major employees is important to the long-term health and success of any organization.

Employee retention focuses on the number of existing workers who remain in their places of work despite the challenges or benefits. Retention policy focuses on holding the high performers and gifted employees (Blake, 2009). The way to retain core employees is one in every of the largest issues that plague firms during this difficult period. Employees acknowledge that the traditional psychological contract that use to exist between a manager and employee is currently dissolved (Hay \& Kearney 2001). Within the current difficult and tough times, reward systems play important roles in retaining employees who serve as the foremost vital asset of the organization (Qureshi et al, 2010). In order to retain the extremely competent and complete employees, human resources management practices like reward systems are being employed (Byrne et al, 2010). Effective reward systems give a confirmative work atmosphere that affords opportunities to grow and develop and additionally discourages activity quality of labour.

Hytter (2007) pointed out that, in many organizations it is desirable to have long tenured employees, although this situation taken to an extreme can also create a problem. Effective management of employee retention is focused primarily on those groups of staff you employ whose resignations are the most problematic from the organization's point of view. Kuvaas et al. (2017) opined that, intrinsic rewards or motivational factors are non-monetary factors that could increase the level of satisfaction among the employees, while the extrinsic motivational factors or rewards are monetary factors that increase the level of satisfaction in the employees. It's the responsibility of the manager to retain their best workers by means of providing engaging rewards. However, there's a natural inequality between what employees assume they must be paid and what organizations pay as rewards. Once the inequality becomes too massive and another chance comes, turnover happens (Kondratuk et al, 2004). Therefore, Eliza and Kin (2020), discovered that work pointers and support throughout a tough time are always a sigh of relief that helps the employees to regain their confidence and motivation. This is often therefore as a result of these measures if well-articulated and 
enforced can increase the extent of motivation of the workers and satisfies their wants.

Employees are the backbone of an entity and their existence and retention in the organization should be the concern of the establishment. Pillay (2009) contended that many foreign organizations especially in western countries offer better rewards than in Africa therefore many of Africa's health professionals have been contemplating going overseas. This brain drain is a problem that needs to be addressed. Retention of the employees is a broad concept, and lots of companies look serious in this provision to maintain a healthy output with their employees (Bisht et al., 2016). The retention of the employees is associated directly with the policies made and implemented by the organization. It is therefore important for an organization to provide their employees with means and rewards that can significantly satisfy their needs professionally and ethically. This is critical because in the views of Al-sharafi et al. (2018), the retention of the employees increases with their motivation or good reward system. These reward system which often comes in form of employees' motivation are grouped into intrinsic factors and extrinsic factors. Both of these reward systems are essential in promoting employee's effectiveness and enhance their retention on the job. Hence, Dhanya and Prashath (2019) pointed out that reward or motivation is a driving force that enables an employee to become reactive, efficient and productive. This implies that good reward system of the employees could maximize the potential and satisfaction level of the employees that ultimately increases the values and productivity of the companies in the long run.

Many efforts are created by Governments to take a position massively in job retention schemes to stem job losses in response to the COVID-19 crisis. These ways embrace participating some countries to require active measures so as to rescale existing short time work (STW) schemes that provides subsidies to companies to hide all or a part of the value of hours not worked, protective workers' financial gain and mitigating prices for companies, yet, employee retention remains a challenge particularly within the health sector (Organization of Economic Cooperation and Development, 2020). The design of these schemes vary considerably across countries because countries usually take different approaches to ensure cost-effectiveness during the pandemic (Hijzen \& Venn, 2011). In Plateau State, the COVID-19 Endowment Fund was launched by the executive governor to fight against the pandemic (WHO, 2020). Yet, as at June 2020, The Plateau State Government disclosed that 29 of its health workers have been infected with the corona virus. The state closed down a private hospital for two weeks, following its exposure to two COVID-19 patients, who were managed for other health conditions. This suggests that no organization was immune of the consequences of the Covid-19 pandemic in the State. Consequently, Quaedackers et al. (2020) suggested that employees' friendly strategies should have been used by the Government and workplaces to reduce the negative impact of Covid-19 pandemic, and make the employees more satisfied and productive. In other words, during the pandemic, the reward system employed by employers of labour should be an important factor in determining employee's retention.

However, to the best of the researcher's knowledge, previous researchers such as Terera \& Ngirande, 2014; Oyoo, et al., 2016 and Rotich, 2020 who have investigated on the effects of reward system on retention related variables have not in any way considered this topic as it concerns the Jos University Teaching Hospital, Plateau State.

\section{STATEMENT OF THE PROBLEM}

The worldwide internment of companies and organisations that were mandated to curtail the unfold of the virus generated a good formation of challenges for each employee and employer worldwide. Terera and Ngirande (2014) stated that the problem faced by many organisations today is their inability to come up with a structured reward strategy for retaining these competent employees for the flourishing of the organization. Furthermore, 17 staff of JUTH were said to have tested positive to the disease, while most staff of the hospital have been quarantined. The WHO (2020) reported that as at September 2020, Plateau was at a point ranked fourth highest in the number of COVID-19 cases in the country, with 3,175 cases, with 62 health workers affected, while 922 patients of the disease were on admission. This posed a great threat on health workers as many health professionals leave the public sector to join the private sector where better rewards are offered.

During the months of unexpected remote working and exceptional working conditions, many employees have experienced high levels of stress and anxiety. Now, some employees fear the perspective of returning to the workplace, while others fear the increased workload. Many employees suffered due to incertitude and lack of direct communication, feeling disoriented and de-motivated thereby posing perceived threats to employees' retention. Many scholars (Terera \& Ngirande, 2014; Oyoo, et al., 2016; Rotich, 2020) among others have investigated the effects of reward system on retention related variables, but to the best of the researcher's knowledge, none of these previous studies concentrated on rewards system and job retention during COVID-19 pandemic in the Jos University Teaching Hospital. This is calls for investigation in this field of study.

\section{Research Questions}

1. What is the effect of extrinsic rewards on employee's retention in Jos University Teaching hospital (JUTH) during covid-19 pandemic?

2. What is the effect of intrinsic rewards on employee's retention in Jos University Teaching hospital (JUTH) during covid-19 pandemic?

\section{Objectives of the Study}

The aim of the study is to evaluate reward system and employees' retention in JUTH in Plateau State. However, the following are the specific objectives of the study:

1. To examine the effect of extrinsic rewards on employee's retention in Jos University Teaching hospital (JUTH) during covid-19 pandemic

2. To evaluate the effect of intrinsic rewards on employee's retention in Jos University Teaching hospital (JUTH) during covid-19 pandemic

\section{Research Hypotheses}

The following hypotheses were formulated to guide the 
HO1: Intrinsic rewards have no significant effects on employee's retention in Jos University Teaching hospital (JUTH) during covid-19 pandemic

$\mathrm{HO}_{2}$ : Extrinsic rewards have no significant effects on employee's retention in Jos University Teaching hospital (JUTH) during covid-19 pandemic

\section{LITERATURE REVIEW}

\section{Concept of Reward System}

Precisely, the term rewards can be defined as a particular monetary return, object or event that an employee receives in reciprocity for his/her work or for having done a good job (Schultz, 2006). According to Dhanya and Prashath (2019), reward is a driving force that enables an employee to become responsive, structured and high-yielding in an organization. This implies adequate motivation or rewards if provided to employees could improve the potential and satisfaction level of the employees that ultimately increases the values and productivity of the companies in particular. Nelson and Peter (2005) stated that "you get what you reward". Hence, a reward system is the world's largest management idea. An organization gets more performance from employees according to the rewards given to the employees (Svensson, 2001). Every surviving organization has some form of reward system, whether it is open or not, it definitely exists (Jaghult, 2005). A reward system binds employees together and creates good relationship between them and with the organization's objectives. Rewards are expected to capture the employees' attention and at the same time it works as a reminder for the person in charge of what needs should be completed in different working areas Oyoo, Mwandihi and Musiega (2016). They further classified reward system into extrinsic rewards and intrinsic rewards.

Extrinsic rewards can be grouped into seven forms: compensation, benefits, workplace environment, recognition, development and feedback, promotion and career opportunities, and leadership (Guest, 2002). Extrinsic reward has to do with physical benefits provided by the organization such as pay, salaries, bonus, fringe benefits and career development opportunities. Intrinsic rewards on the other hand, has to do with rewards that come from the content of the job itself and comprises of motivational attributes of the job such as independence, role coherence and education (Salah, 2016). According to the authors, extrinsic rewards may also include external rewards such as incentives, promotions, job security and contract of service, allowances and insurance. Intrinsic rewards on the other hand may include other factors such as, appreciation, meeting the new challenges, positive and caring attitude from employers, job rotation, and sense of achievement, professional growth and individual recognition.

\section{Employee Retention}

Employees are the cornerstone of an organization and their existence is very important. According to Zineldin (2000), employee retention is a duty to persist in doing business or exchange with a particular company on a progressive manner. Retention of the employees is a broad concept, and lots of companies try to maintain a healthy output with their employees (Bisht et al. 2016). Employee retention is a vital element in the survival and success of an organization and should be considered when developing strategies and plans to ensure a competent skilled workforce that delivers the organizations' skills and goals (Rotich 2020). Employee retention basically comprises of issues of remuneration, cash incentives, work life balance, supervisor support and employee recognition (Mendis, 2017). People are rewarded financially for the job they are doing and may receive additional rewards related to the level of their performance, competence or skills (contingent or variable pay) or their service in the job (service-related pay). They can also receive nonfinancial rewards such as recognition, praise or the opportunity to develop and learn new skills (Mamo, 2017). This means that reward that JUTH employees need to enable them stay in the organization must not necessarily take the form of cash or monetary rewards; verbal rewards and access to other services at no cost can help in this regard.

However, if an organization is not able to retain its employees, it will not be able to capitalize on human assets developed within the organization. Literature and best practices indicate that, to some extent, if employers treat their employees well by way of rewarding them, they will not be tempted to look for alternative jobs. The retention of the employees increases with their motivation (Al-sharafi et al., 2018). It is therefore of great importance that organizations keep their employees satisfied to improve employee retention. According to Denton (2000), employees who are excited and contented with their jobs are more committed towards their work and often seek to do their best to satisfy their organizational customer's satisfaction. Employee retention is a situation where employees are motivated to stand with the organization until the aims and objectives of the organization are achieved.

Furthermore, Achieng (2011) stated that, employee retention is the ability of an organization to retain its employees. Going by her definition, most organizations are being carried away by their business performance at the end of each year but fail to consider all the factors that influence employee's retention required to stimulate higher performance. Similarly, Ng'ethe et al. (2012) opined that workers are thought-about because they are the most useful asset of all organizations as they supply competitive advantage to an organization, therefore, retaining them in their job is essential. Elsafty and Ragheb (2020) opined that the natural event of the COVID-19 pandemic has created lots of instabilities everywhere in the globe. This means that the success of any organization lies within the quality of its workers and this may solely be achieved if they are rewarded accordingly especially during a period of pandemics.

\section{EMPIRICAL REVIEW}

During a study conducted by Terera and Ngirande (2014) on the impact of rewards on job satisfaction and worker Retention in Rome-Italy, it absolutely was unconcealed that employee rewards cause employee retention however but, they do not end in job satisfaction. This study has relevance to the present study due to the fact that it captured the variables of interest. However, whereas the researchers focused on Rome-Italy, this study focused on Jos University Teaching Hospital in Plateau State, Nigeria.

Similarly, Oyoo, et al. (2016) studied the influence of reward systems on employees' retention in faith-based health organizations in Kenya: A case of Mukumu Hospital, Kenya. The study noted that there was a robust and direct correlation between 
employee retention and intrinsic rewards that was statistically important. There was conjointly a robust and direct correlation between the employees' retention and extrinsic rewards that was a sign that extrinsic rewards have positive influence on worker retention. Career development conjointly absolutely influenced the retention of faith-based health organization workers in African nation. The study concluded that intrinsic, extrinsic as well as career development are important components of employee retention. The scholars focused on faith-based hospitals, whereas this research is on Jos University Teaching Hospital which is a public tertiary hospital.

Rotich (2020) investigated the consequences of reward management practices on employee retention in telecommunication corporations in African nation. The study found that there was a robust link between employees' reward management practices and retention in telecommunication corporations. The study concluded that reward management has a high effect on employee performance such that the more efficiently an organization manages it rewards, the better the employees will perform. The researcher however failed to explain how each of the reward impacted on employees' retention as captured in this study.

Furthermore, Elsafty and Ragheb (2020) examined the role of human resources management towards the employees as far as curbing the adverse impact of Covid-19 is concerned. The quantitative method was used in this research in which a total of 140 respondents were selected using the non-probability sampling. Descriptive Statistics and Correlation metrics were used for data analysis. The study found that Human Resources managers should play their role in maximizing the satisfaction level of their employees. It concluded that workplace guidelines and support and access to Information and financial benefits were some of the main elements that should have been considered by the entities for maximizing their income potential and values. This study covered the period of covid-19 pandemic, but it was not delimited to reward system and retention in an organization which are the subjects of concern in the research.

\section{Explanatory Variables}

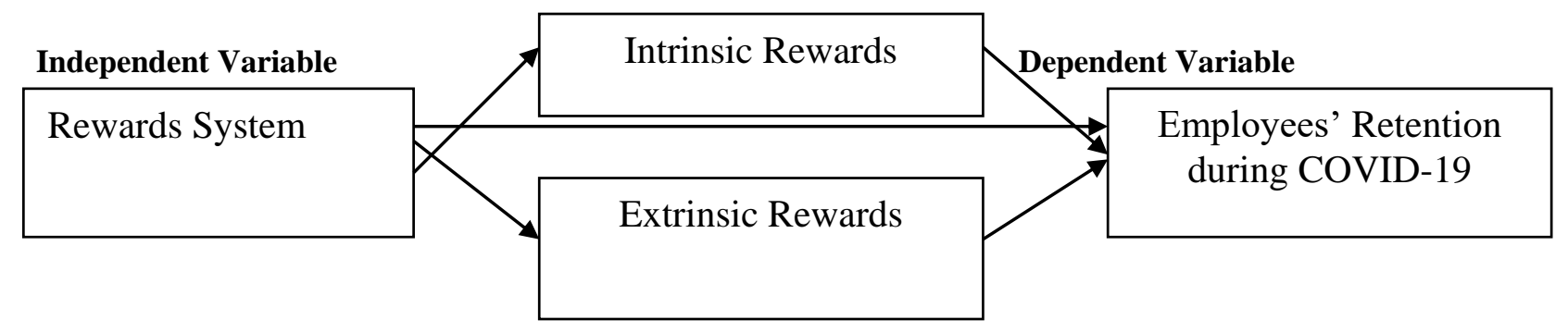

Figure 1: Researchers' Conceptual Framework, 2020

The conceptual framework in figure 1 shows that JUTH reward system can take the form of either intrinsic or extrinsic rewards. Each of these rewards affects employees' retention during COVID-19 as indicated by the two arrows. This implies that though a direct relationship exists between reward system and employees' retention, the effect can better be explained by looking at the effect of each of the reward systems on retention.

\section{Theoretical Review}

This work is anchored on Vroom's Expectancy Theory which tries to explain the motivated behavior as goal oriented. He argues that people tend to act in a pleasure-seeking way (Vroom, 1964) preferring the actions that will bring the highest subjective utility. The theory stated that the greater the value-added on a set of rewards, the higher the possibility that acknowledging each of these rewards depend upon effort, the bigger the effort that will be put in a given situation. The theory has four basic assumptions. The first assumption is that people join organizations with high expectations about their needs, motivations, and past experiences which have a great impact on how individuals respond to their roles in the organization. The second assumption is that an individual's conduct is a result of deliberate options. That is, people are free to choose those conducts suggested by their own expectancy estimations. The third assumption is that people want so many things from their organizations. These needs include good salary, job security and promotion. The fourth assumption is that people will choose among other options so as to maximize outcomes for themselves (Lunenburg, 2011).

According to Vroom (1964), people will give their best in attaining to the organizational objectives if they are sure of a favorable reward. Organizations must understand that individuals respond differently according to how they are being motivated; some individuals may be motivated by recognition while others may be motivated by bonuses or benefits (Rotich, 2020). Expectancy theory further asserts that employees have high expectations from their employers or managers in the sense that employers will make available important information concerning their job and also provide them with sufficient training so as to enable them perform their roles effectively and efficiently for the success of the organization. This theory is relevant to the study considering the fact that employees' of JUTH have among others the task of contributing to the goals and objectives of JUTH as an organization. They therefore need to be motivated by rewards that can spur them to put in their best especially during the covid 19 pandemic.

\section{Methodology: \\ Research Design}

The study was designed as a descriptive survey study. This is so because the study described a situation and its minimum bias in the collection of data. According to Wanjau and Wanarigi (2012), a descriptive design describes population characteristics 
by the selection of equal sample. It is concerned with finding out the what, where and how of a phenomenon. The researcher administered a questionnaire to each member of the target population comprising questions in line with the study.

\section{Population and Sample}

The study population comprises of male and female Staff of JUTH working as physicists, nurses, laboratory technicians, Xray technicians, Pharmacists, Physiotherapists, druggists, administrators and those in the finance department. Hence, a target population of 400 staff was considered, out of which 100 respondents were selected for the study. According to Mugenda and Mugenda (2003), in a survey research a sample size of 10$30 \%$ is considered enough and appropriate for the study. Therefore, these sampled participants were selected using simple random sampling, but the selection on their various professions was done using purposive sampling technique. This was employed because the researchers had predetermined purposes which are to ensure that these professions are included in the study sample.

\section{Instrument for Data Collection}

The COVID-19 and employee reward and retention system questionnaire (CERRS-Q) was employed as instrument for data collection. The questionnaire was adopted from the work of Oyoo, Mwandihi and Musiega (2016) and administered to all the sampled respondents. All respondents were asked to rate their reward systems and employee retention amidst Covid-19 pandemic on a 5-point Likert Scale. In this scoring system, participants responded to each of the five response categories as Strongly Agree $(\mathrm{SA}=5)$, Agree $(\mathrm{A}=4) 3=$ Neutral $(\mathrm{N}=3)$ Disagree, $(\mathrm{D}=2)$ and Strongly Disagree $(\mathrm{SD}=1)$ respectively. The instrument was administered to the sampled participants using the face-toface or direct method of administration by the researchers and two research assistants who were staff of the organization.

\section{Method of Data Analysis}

Out of the one hundred (100) questionnaires that were issued out to the respondents, eighty (80) were filled and returned. Descriptive statistics, principally simple percentages, mean rating and standard deviations were used in analyzing the research objectives. A criterion means of 3.0 which is average of the 5-point Likert scale was used in interpreting the estimated coefficients for each of the items. Spearman Rank Correlation was the inferential statistic used for hypotheses testing. All hypotheses were tested at 0.05 level of significance, while probability values were used for statistical decisions.

\section{RESUlts}

Table 1: Descriptive Analysis of Socio-Demographic Data

\begin{tabular}{llll}
\hline Variable & & Frequency $\mathbf{( n = 8 0 )}$ & Percentage $\mathbf{( \% = 1 0 0 )}$ \\
\hline Gender & Male & 35 & 43.8 \\
& Female & 45 & 56.3 \\
Tge Bracket & Total & $\mathbf{8 0}$ & $\mathbf{1 0 0 . 0}$ \\
& $17-24$ years & 10 & 12.5 \\
& $25-34$ years & 25 & 31.3 \\
35-44 years & 35 & 43.8 \\
Working Experience & 45 and Above & 10 & 12.5 \\
& Total & $\mathbf{8 0}$ & $\mathbf{1 0 0 . 0}$ \\
& 0-10 years & 28 & 35.0 \\
& 11-20 years & 30 & 37.5 \\
Profession & 21-30 years & 20 & 25.0 \\
& 31 years and above & 2 & 2.5 \\
& Total & $\mathbf{8 0}$ & $\mathbf{1 0 0 . 0}$ \\
& Physicists & 10 & 12.5 \\
& Nurses & 30 & 37.5 \\
& Lab.Technicians & 10 & 12.5 \\
& X-Ray technicians & 3 & 3.8 \\
& Pharmacists & 6 & 7.5 \\
& Physiotherapists & 5 & 6.3 \\
& Druggists & 5 & 6.3 \\
& Administrators & 7 & 8.8 \\
& Finance & 4 & 5.0 \\
& Total & $\mathbf{8 0}$ & $\mathbf{1 0 0 . 0}$ \\
\hline
\end{tabular}

Source: Field Survey, 2020

The findings revealed that 43.8 percent of the respondents were male and 56.3 percent were female. This implies that majority of the respondents were female employees' of JUTH. The results also revealed that majority of the respondents (43.8) percent were aged 35-44 years, 37.5 percent and majority of the participants (38.5\%) have worked for 11-20 years. The findings further revealed that most of the participants $(37.5 \%)$ also were nurses. This implies that the participants cut across different professions in the organizations. 
Table 2: Mean Rating of Effect on Intrinsic Reward on Job Retention during COVID-19

\begin{tabular}{lllll}
\hline SN. & Statement of Items & Mean & Std. Dev. & Ranking \\
\hline 1 & I understand the intrinsic rewards the organization provides & 3.000 & 1.331 & $8^{\text {th }}$ \\
2 & The organization's intrinsic rewards promote commitment & 3.388 & 1.355 & $3^{\text {rd }}$ \\
3 & $\begin{array}{l}\text { The organization's reward system recognizes superior } \\
\text { performance }\end{array}$ & 2.638 & 1.343 & $10^{\text {th }}$ \\
4 & My achievements give me the zeal to stay in the organization & 3.400 & 1.337 & $2^{\text {nd }}$ \\
5 & My achievements are recognized and acknowledged & 3.025 & 1.432 & $7^{\text {th }}$ \\
6 & The responsibilities I have motivate me to remain in this & 3.475 & 1.396 & $1^{\text {st }}$ \\
& $\quad$ & & \\
7 & organization & & \multicolumn{2}{|c}{$5^{\text {th }}$} \\
8 & The responsibilities I am given are fitting my qualifications & 3.325 & 1.421 & $4^{\text {th }}$ \\
9 & My efforts are acknowledged in this organization & 3.375 & 1.173 & $6^{\text {th }}$ \\
10 & I am proud of my work in this organization & 3.250 & 1.530 & $9^{\text {th }}$ \\
\hline
\end{tabular}

The results of the analysis revealed that the responsibilities they have, motivated them to remain in the organization ( $1 s t)$, some said their achievements give them the zeal to stay in the organization $(2 n d)$, the organization's intrinsic rewards promote commitment $(3 r d)$ and their efforts are acknowledged in the organization $(4 t h)$. They argued that their responsibilities in office fit their qualifications (5th), they are proud of their work in the organization $(6 t h)$, their achievements are recognized and acknowledged $(7 t h)$ and that they understand the intrinsic rewards the organisation provides $(8 t h)$. These are the intrinsic rewards systems that contributed to the employees retention in the organisation because they had mean estimates that are greater than 3.0 used as the decision mean.

Table 3: Mean Rating of Effect of Extrinsic Reward on Job Retention during COVID-19

\begin{tabular}{|c|c|c|c|c|}
\hline SN. & Statement of Items & Mean & Std. Dev. & Ranking \\
\hline 1 & I am satisfied with my pay & 2.938 & 1.353 & $4^{\text {th }}$ \\
\hline 2 & Benefits provided by the organization are satisfying & 2.700 & 1.287 & $7^{\text {th }}$ \\
\hline 3 & I am satisfied with the bonuses I get in my job & 2.463 & 1.102 & $9^{\text {th }}$ \\
\hline 4 & My organisation's pay is benchmarked to the market & 3.125 & 1.173 & $3^{\text {rd }}$ \\
\hline 5 & My organisation's pay is competitive & 3.250 & 1.258 & $2^{\text {nd }}$ \\
\hline 6 & The promotion systems of the organization is fair & 2.467 & 1.113 & $8^{\text {th }}$ \\
\hline 7 & $\begin{array}{l}\text { I am satisfied with the allowance I get at the organization } \\
\text { based on my grade }\end{array}$ & 2.550 & 0.992 & $5^{\text {th }}$ \\
\hline 8 & $\begin{array}{l}\text { My pay and grade are commensurate with my colleagues in } \\
\text { the same job }\end{array}$ & 3.750 & 1.207 & $1^{\text {st }}$ \\
\hline 9 & I am paid for any overtime I work & 2.713 & 1.265 & $6^{\text {th }}$ \\
\hline
\end{tabular}

The analysis of measures of extrinsic rewards and employees retention showed that respondents said their pay and grades are commensurate with those of their colleagues in the same job $\left(1^{\text {st }}\right)$, they maintained that the organization's pay is competitive $\left(2^{\text {nd }}\right)$ and is benchmarked to the market $\left(3^{\text {rd }}\right)$. These items had their mean greater than 3.0 used as criterion mean, which also means that they are the major extrinsic rewards system that ensure their retention. However, it was found that the respondents are not satisfied with their salaries/pay $\left(4^{\text {th }}\right)$ and the allowances they get based on their grade level $\left(5^{\text {th }}\right)$ because they are not paid for overtime work $\left(6^{\text {th }}\right)$. The results showed that the benefits provided by the organization are not satisfying $\left(7^{\text {th }}\right)$ because the promotion system of the organization is not fair $\left(8^{\text {th }}\right)$ and they are not satisfied with the bonuses they get in their jobs $\left(9^{\text {th }}\right)$.

Table 4: Spearman Rank Correlation of Effect of Intrinsic Rewards on Job Retention during Covid-19

\begin{tabular}{lllll}
\hline Test Statistic & & Intrinsic Reward & Job Retention \\
\hline Spearman's rho & Intrinsic Reward & Correlation & 1.000 & $.946^{* * *}$ \\
& & Coefficient & & .000 \\
& Sig. (2-tailed) &. & 80 \\
& $\mathrm{~N}$ & 80 & 1.000 \\
& Job Retention & Correlation & $.946^{* * *}$ & \\
& & Coefficient & .000 & 80 \\
\hline & Sig. (2-tailed) & N & 80 & \\
& & & \\
& & &
\end{tabular}


The findings from Table 4 showed that $\mathrm{r}(80=.946, \mathrm{p}=.000)$, which implies that $\mathrm{p}<0.05$; hence the null hypothesis was rejected. The conclusion drawn is that intrinsic rewards system has significant positive effect on employees' retention during COVID-19 pandemic in JUTH.

Table 5: Spearman Rank Correlation of Effect of Intrinsic Rewards on Job Retention during Covid-19

\begin{tabular}{lllll}
\hline Test Statistic & & & Extrinsic Reward & Job Retention \\
\hline Spearman's rho & Extrinsic Reward & Correlation & 1.000 & $.933^{* *}$ \\
& & Coefficient & & .000 \\
& Sig. (2-tailed) &. & 80 \\
& N & 80 & 1.000 \\
& \multirow{3}{*}{ Job Retention } & Correlation & $.933^{* *}$ & \\
& & Coefficient & .000 &. \\
& Sig. (2-tailed) & 80 & 80 \\
\hline
\end{tabular}

Table 5 indicated that $\mathrm{r}(80=.933, \mathrm{p}=.000)$, which means that $\mathrm{p}<0.04$. Based on this, the null hypothesis was rejected and the study concluded that extrinsic rewards system has significant positive effect on employees' retention during COVID-19 pandemic in JUTH.

\section{Discussion of Findings}

The findings from the analysis of the effect of intrinsic rewards on employees' job retention indicated that the responsibilities they have motivate them to remain in this organization, some said their achievements give them the zeal to stay in the organization, the organization's intrinsic rewards promotes commitment and their efforts are acknowledged in this organization. It was also found that JUTH employees' responsibilities in the office fit their qualifications, they are proud of their work in this organization, their achievements are recognized and acknowledged and that they understand the intrinsic rewards the organisation provides. The results agreed with the view of Dhanya and Prashath (2019) that motivation or reward is a driving force that enables an employee to become reactive, efficient and productive. High reward in form of motivation of the employees could maximize the potential and satisfaction level of the employees that significantly increases the values and productivity of the organization. Wassem et al., (2019) asserted that communicating with the employees from the management and informing them about the pandemic and its intensity could be ideal for the employees to get satisfied and remain with the organization. The study found that intrinsic rewards system has significant positive effect on employees' retention during COVID-19 pandemic in JUTH. This implies that an increase in the provision of intrinsic rewards during the Pandemic of Covid-19, will lead to a higher retention of the employees.

Furthermore, the analysis of the effect of extrinsic rewards on employees' job retention showed that respondents said their pay and grades are commensurate with those of their colleagues in the same job, they maintained that the organization's pay is competitive and is benchmarked to the market. However, it found that the respondents said they are not satisfied with their salaries/pay and the allowances they get based on their grade level because they are not paid for overtime work. Thus, the study showed that most of the extrinsic rewards were not provided during the pandemic. Buttressing this, Al-sharafi, et al. (2018) pointed out that the retention of the employees' increases with their motivation. The results also showed that the benefits provided by the organization are not satisfying because the promotion system of the organization is not fair and they are not satisfied with bonuses they get in their jobs. The findings also revealed that extrinsic rewards system has significant positive effect on employees' retention during COVID-19 pandemic in JUTH. This is in consonance with the study of Rotich (2020) who found that there is a strong link between employees' reward management practices and retention in telecommunication firms.

\section{CONCLUSION}

Rewards made available to employees have been identified in literature as an important determinant of employees' retention in an organization. The findings from this study showed that both intrinsic and extrinsic reward systems are provided to employees of Jos University Teaching Hospital (JUTH), in Plateau State. It was found that intrinsic rewards in form of the responsibilities they have motivate them to remain in the organization, their achievements give them the zeal to stay in the organization and the organization's intrinsic rewards promotes commitment. The study revealed that employees' extrinsic rewards such as their pay and grades are commensurate with those of their colleagues in the same job; the organization's pay is competitive and is benchmarked to the market. However, it argued that they are not satisfied with their pay and the allowances they get during COVID-19 pandemic. The results showed that both intrinsic and extrinsic rewards systems have significant positive effects on employees' Job retention in JUTH and concluded that rewards system affect employees' retention in Nigeria.

\section{Recommendations}

i. The Government and management of JUTH should redesign their intrinsic reward system policy in a manner than superior performance by employees' will attract special rewards so as to promote staff retention.

ii. Management of JUTH should ensure that employee' benefits, allowances and promotions are given to them at the right time so as to retain them in the job.

iii. Government should ensure that reward system for JUTH staff takes into cognizance novel diseases such as 
pandemics so as to minimize their consequences on employees' retention.

\section{REFERENCES}

[1] Achieng, N.P. (2011). Perceived effects of Employee Benefits on Employee Retention At Kenya Forest Service (M.Sc dissertation), University Of Nairobi.

[2] Al-sharafi, H., Hassan, M. E. M., \& Alam, S. S. (2018). The effect of training and career development on employee's retention: A study on the Telecommunication Organizations in Yemen. The Journal of Social Sciences Research, 420-430.

[3] Blake, R. (2009). Employee Retention - 9 Unnecessary Reasons Employers Lose Good Employees. Retrieved June 9, 2020

[4] Bisht, S., Chaubey, D. S., \& Thapliyal, S. P. (2016). Analytical study of psychological contract and its Impact on Employees Retention. Pacific Business Review International, 8(11),45-56

[5] Byrne, Z.S., Miller. B. K. \& Pitts. V. E. (2010). Trait entitlement and perceived favorability of human resource management practices in the prediction of job satisfaction. J. Bus. Psychol., 25: 451-464.

[6] Denton J. (2000). Using Web-based projects in a systems design and development Course. Journal of Computer Information Systems. 40(3):85-7.

[7] Dhanya, M. R., \& Prashath, R. T. (2019). A study on drivers of employee engagement and employee retention in healthcare sector, Tiruchirappali Corporation. Journal of the Gujarat Research Society, 21(7), 222-233.

[8] Eliza, L. W. \& Kin, F.(2020). Workplace safety and coronavirus disease (COVID-19) pandemic: survey of employees. Public Health and Care Facility, 12(2). https://10.2471/BLT.20.255893

[9] Elsafty, A.S. \& Ragheb, M. (2020). The role of human resource management towards employees retention during Covid-19 pandemic in medical supplies sector -Egypt. Business and Management Studies, 6 (2),1-11.

[10] Guest, D. (2002). "Human resource management, corporate performance and employee wellbeing: building the worker into HRM", Journal of Industrial Relations, 44(3), 335- 358

[11] Hays, S.W. \& Kearney R.C. (2001). Anticipated Changes in Human Resource Management: Views from the Field. Public Administration Review; 61(5):585-592.

[12] Hijzen, A. \& Venn, D. (2011). "The Role of Short-Time Work Schemes during the 2008-09 Recession", OECD Social, Employment and Migration Working Papers, No. 115, OECD Publishing, Paris, https://10.1787/5kgkd0bbwvxp-en.

[13] Hytter, A. (2007). Retention strategies in France and Sweden. The Irish Journal of Management, 28(1), 59-79.

[14] Jaghult, B. (2005). Management of Rewards in Organizations, Sollentuna: Non-Stop Communications.

[15] Kondratuk, T. B; Hausdorf, P.A.; Korabik, K. \& Rosin, H. M. (2004). Introduction Of Employee Retention - A Conceptual Framework. Journal of Vocational Behaviour, 65 (2), 332-349.

[16] Kuvaas, B., Buch, R., Weibel, A., Dysvik, A., \& Nerstad, C. G. (2017). Do intrinsic and extrinsic motivation relate differently to employee outcomes? Journal of Economic Psychology, 61, 244-258. https://10.1016/j.joep.2017.05.004

[17] Lunenburg, F.C. (2011). Expectancy Theory of Motivation: Motivating by Altering Expectations. International Journal of Management, Business, and Administration 15(1).

[18] Mamo, M. (2017). The Impact of Reward Management Systems on Employee Retention:

[19] The Case of CURE Hospital, (BSc. dissertation) Addis Ababa University, School of Commerce.

[20] Mendis, M.V.S (2017). The Impact of Reward System on Employee Turnover Intention: A Study on Logistics Industry of Sri Lanka. International Journal of Scientific \& Technology Research. 6(9) 67-72.
[21] Mugenda O. \& Mugenda G. (2003). Research methods: Quantitative and qualitative approaches. African Centre for Technology Studies.

[22] Nelson, B. \& Peter, E. (2005). Management Bible, Sweden: John Wiley and Sons Incorporated.

[23] Ng"ethe, J.M., Iravo, M.E. \& Namusonge, G.S. (2012). Determinants of Academic Staff Retention in Public Universities in Kenya: Empirical Review. International Journal of Humanities and Social Science, 2(13), 205-212.

[24] Oyoo,M.O, Mwandihi,N.K, Musiega, D. (2016). Influence of reward systems on employee retention in faith-based health organizations in Kenya: a case of Mukumu Hospital, Kenya. International Journal of Commerce and Management Research, 2(10); 42-51

[25] OECD (2020). OECD Employment Outlook 2020: Worker Security and the COVID-19 Crisis, OECD Publishing, Paris, https://10.1787/1686c758-en.

[26] Pillay, R. (2009). "Work satisfaction of professional nurses in South Africa: a comparative analysis of the public and private sectors", Human Resources for Health, 7(1), 15-27.

[27] Quaedackers, J. S., Stein, R., Bhatt, N., Dogan, H. S., Hoen, L., Nijman, R. J. \& Bogaert, G. (2020). Clinical and surgical consequences of the COVID-19 pandemic for patients with pediatric urological problems. Statement of the EAU guidelines panel for pediatric urology, Journal of Pediatric Urology. https://10.1016/j.jpurol.2020.04.007.

[28] Qureshi, T.M., Akbar, A., Khan, M.A., Sheikh, R.A., \& Hijazi, S.T. (2010) Do human resource management practices have an impact on financial performance of banks? African Journal of Business Management,4(7), $1281-1288$

[29] Rotich, R. (2020). Effects of Reward Management Practices on Employee Retention in Telecommunication Firms in Kenya. International Journal of Economics, Commerce and Management. 8(2), 500-526.

[30] Salah, M.R (2016). The Influence of Rewards on Employees Performance. British Journal of Economics, Management \& Trade. 13(4): 1-25. https://10.9734/BJEMT/2016/25822.

[31] Schultz, W. (2006). Behavioral theories and the neurophysiology of reward, Annual Review of Psychology, 57, 87-115.

[32] Sharma, G. D., Mahendru, M., \& Singh, S. (2010). A Study of Employee Retention in ITeS Industry: A Case of North India. Res Manageria, 1(1). Retrieved October 20, 2020, from: https://ssrn.com/abstract=1827482

[33] Svensson, A. (2001). Reward System, Stockholm: KFS Foretagsservice

[34] Vroom, V.H. (1964). Work and motivation. New York, NY: Wiley.

[35] Wanjau K, \& Wanarigi B. (2012). Factors affecting provision of service quality in public health care a case of Kenyatta National Hospital. International journal of humanities and social sciences.

[36] Wassem, M., Baig, S. A., Abrar, M., Hashim, M., Zia-Ur-Rehman, M., Awan, U., \& Nawab, Y. (2019). Impact of Capacity Building and Managerial Support on Employees' Performance: The Moderating Role of Employees' Retention. SAGE Open 9(3), 2158244019859957.https://10.1177/215824401985995,WorldHealth Organization. Situation Report

[37] Zineldin, M., (2000). TRM Total Relationship Management, Studentlitteratur, Lund.

\section{AUTHORS}

First Author - Zoakah, Dogonyaro Joy, Department Of Business Administration, Faculty Of Management Sciences University Of Jos, zoakahdjoy @ gmail.com, 08032347730

Second Author - Bulus Pikitda, Texila American University, Guyana,bpikitda@yahoo.com, 08033670663

Third Author - Comfort Iliya, Ph.D Student, Department Of Business Administration, Faculty Of Management Sciences, University Of Jos, Comfortiliya2016@gmail.com, 08068454982 